\title{
Effects of Carbon Nanotubes Acid Treated or Annealed and Manganese Nitrate Thermally Decomposed on Capacitive Characteristics of Electrochemical Capacitors
}

\author{
Chuen-Chang Lin and Chung-Lun Kuo \\ Department of Chemical \& Materials Engineering, National Yunlin University of Science and Technology, \\ 123 University Road, Section 3, Douliu, Yunlin 64002, Taiwan
}

Correspondence should be addressed to Chuen-Chang Lin; linchuen@yuntech.edu.tw

Received 3 July 2013; Accepted 8 September 2013

Academic Editor: Yun Suk Huh

Copyright (c) 2013 C.-C. Lin and C.-L. Kuo. This is an open access article distributed under the Creative Commons Attribution License, which permits unrestricted use, distribution, and reproduction in any medium, provided the original work is properly cited.

Carbon nanotubes (CNTs) directly grown on aluminum foil or nanoporous alumina templates by chemical vapor deposition are treated with acid for different times or annealed at different temperatures. Then, the CNTs are immersed into a manganese nitrate aqueous solution and then manganese oxides are formed by thermally decomposing the manganese nitrate at different temperatures. The longer the time that the CNTs are treated with the acid, the slower the decreasing rate of the specific capacitance. Also, the higher the annealing temperature of the CNTs, the slower the decreasing rate of the specific capacitance. Furthermore, the electrochemical stability for thermally decomposing manganese nitrate at $400^{\circ} \mathrm{C}$ is better than that at 200 or $300^{\circ} \mathrm{C}$ and the operational stability with nanoporous alumina templates as a substrate is better than that with $\mathrm{Al}$ foil as a substrate.

\section{Introduction}

Electrochemical capacitors are charge-storage devices which possess higher power density/longer cycle life than batteries $[1,2]$ and higher energy density than conventional capacitors [3]. Their applications include hybrid power sources, backup power sources, starting power for fuel cells, and burstpower generation in electronic devices [4-8]. Electrochemical capacitors are classified into two types: electric double layer capacitors (EDLC) and pseudocapacitors according to the energy-storage mechanisms. The capacitance of an EDLC arises from the separation of charge at the interface between the electrode and the electrolyte. However, pseudocapacitance arises from redox reactions of electroactive materials with several oxidation states [1, 9-13].

In our previous study [14], carbon nanotubes (CNTs) which were directly grown on nanoporous alumina templates by chemical vapor deposition were modified by radio frequency nitrogen-plasma for different durations. Other methods for the modification of the physical and chemical properties of carbon materials include acid treatment $[15,16]$ and annealing $[16,17]$. In this study, in order to reduce costs, a simpler physicochemical method of acid-treatment or annealing was substituted for the nitrogen-plasma in the modification of CNTs and for improving their organized carbon and hydrophilic nature. The tips of multiwalled CNTs were opened by boiling in 69 wt.\% nitric acid for durations of 15 to $45 \mathrm{~min}$ and then the multiwalled CNTs were annealed in $\mathrm{CO}_{2}$ at $525^{\circ} \mathrm{C}$ for 60 to $100 \mathrm{~min}$ in order to eliminate the disordered carbon arising from the tips destruction [18]. CNTs were refluxed in $16 \mathrm{M}$ nitric acid for $3 \mathrm{~h}$ and then the CNTs were annealed in nitrogen or hydrogen for $3 \mathrm{~h}$ at $450^{\circ} \mathrm{C}$ or $950^{\circ} \mathrm{C}[19]$. CNTs were firstly oxidized by $\mathrm{H}_{2} \mathrm{O}_{2}$ for opening tube ends as well as shortening the CNT's length, then treated by $\mathrm{HCl}$ for removing the residual oxidized catalyst particles as well as other carbonaceous materials, and finally annealed in air at $450^{\circ} \mathrm{C}$ for $45 \mathrm{~min}$ for maximizing the CNT tip destruction as well as further reducing the amorphous carbon [20]. Single-walled CNTs were annealed in air at increasing temperatures in the range from 300 to $550^{\circ} \mathrm{C}$ for $1 \mathrm{~h}$ [17].

In another previous study [21], manganese-cobalt-zinc oxide films were deposited on graphite foils by radio frequency sputtering with different substrate treatment temperatures and bias potential. In this study, in order to reduce 
cost, a simple wet method of immersion as well as thermal decomposition was used instead of sputtering and manganese oxides were covered on the surface of the CNT matrix by immersion as well as thermally decomposing $\mathrm{Mn}\left(\mathrm{NO}_{3}\right)_{2}$. In another of our previous studies [22], manganese oxide was coated on a graphite electrode by immersion and durations for immersion were varied to control the amount of manganese oxide coated onto the electrode surface. A definite amount of $50 \mathrm{wt} . \% \mathrm{Mn}\left(\mathrm{NO}_{3}\right)_{2}$ aqueous solutions was dripped onto the surface of the CNT electrode by a microsyringe and manganese oxides were formed by thermally decomposing $\mathrm{Mn}\left(\mathrm{NO}_{3}\right)_{2}$ in air at $250^{\circ} \mathrm{C}$ for $2 \mathrm{~h}$ [23]. A mixed aqueous solution of $2 \mathrm{M} \mathrm{Ni}\left(\mathrm{NO}_{3}\right)_{2}$ and $1 \mathrm{M} \mathrm{Co}\left(\mathrm{NO}_{3}\right)_{2}$ was added to the surface of the CNT/graphite electrode by a microsyringe and nickel-cobalt oxides were formed by thermally decomposing nickel as well as cobalt nitrates in air at $250^{\circ} \mathrm{C}$ for $2 \mathrm{~h}$ [24].

The aim of the research described herein is to identify the effects of different substrates, carbon nanotubes acid treated or annealed, and manganese nitrate thermally decomposed on the specific capacitance and operational stability of electrochemical capacitors. Thus, to reduce costs and facilitate scaling up production, the CNTs were modified by the simple physicochemical method of acid treatment for different times or different annealing temperatures and then manganese oxides were deposited on the surface of the CNT matrix by the wet method (immersion) as well as thermally decomposing the $\mathrm{Mn}\left(\mathrm{NO}_{3}\right)_{2}$ at different temperatures in this study.

\section{Materials and Methods}

Aluminum foil $(10 \mathrm{~cm} \times 5 \mathrm{~cm} \times 0.001 \mathrm{~cm}$, purity $99.98 \%)$ was degreased in acetone for $5 \mathrm{~min}$. In order to remove the oxide layer from its surface, it was then immersed in $1 \mathrm{M}$ aqueous $\mathrm{NaOH}$ for $2 \mathrm{~min}$ and subsequently rinsed with deionized water. Next, it was rinsed ultrasonically with alcohol for $15 \mathrm{~min}$.

In order to fabricate well-ordered nanoporous AAO templates through a two-step anodization process, the pretreated aluminum foil was electropolished in a solution of sulfuric acid: phosphoric acid: deionized water in ratios of $2: 2: 3$. Next, for the first anodization of the aluminum foil, $25 \mathrm{~V}$ was applied for $30 \mathrm{~min}$ in a $0.5 \mathrm{M}$ sulfuric acid solution at $5^{\circ} \mathrm{C}$. Etching of the anodized film followed in a mixture of chromic acid (1.8wt.\%) and phosphoric acid (6wt.\%) for $40 \mathrm{~min}$ at $60^{\circ} \mathrm{C}$. Then, the second anodization was performed under the same conditions as the first anodization except for a duration of $210 \mathrm{sec}$. At the end of the second anodization, the previous value of the current density was halved and then the sample was reanodized until reaching a stable potential. This process was repeated eight times until reaching almost 0 $\mathrm{V}$ potential. Finally, the pores of AAO templates were further widened after the second anodization by etching in phosphoric acid (5 wt.\%) for $20 \mathrm{~min}$. This was in order to completely remove the aluminum oxide (barrier layer) on the pore bottom tips of the AAO templates and then electrochemically deposit catalyst particles at the pore bottom tips of AAO templates.
Before carbon nanotube growth, the cobalt (Co) catalyst particles were electrochemically deposited on the pretreated aluminum foil or at the pore bottom tips of AAO templates in an electrolyte of $\mathrm{CoSO}_{4} \cdot 7 \mathrm{H}_{2} \mathrm{O}$ (5 wt.\%) and $\mathrm{H}_{3} \mathrm{BO}_{3}$ (2 wt.\%) by applying an alternating current voltage of $10.5 \mathrm{~V}$ (frequency: $60 \mathrm{~Hz}$ ) for $60 \mathrm{sec}$. Next, CNTs were grown on the Cocoated aluminum foil or the Co-coated nanoporous alumina templates using thermal CVD with the gas mixture $\left(\mathrm{C}_{2} \mathrm{H}_{2}=\right.$ $50 \mathrm{sccm}$ and $\mathrm{Ar}=100 \mathrm{sccm}$ ) at $600^{\circ} \mathrm{C}$ for $60 \mathrm{~min}$.

The CNT electrodes were immersed in $61 \mathrm{wt} . \% \mathrm{HNO}_{3}$ aqueous solution for different durations $(0,5,10$, and $15 \mathrm{~min})$ or annealed at different temperatures $\left(300,350\right.$, and $400^{\circ} \mathrm{C}$ ) in air for $1 \mathrm{~h}$.

After being acid treated or annealed in air, the CNTs were immersed into a $50 \mathrm{wt} . \% \mathrm{Mn}\left(\mathrm{NO}_{3}\right)_{2}$ aqueous solution for $5 \mathrm{~min}$. Then, manganese oxides were formed by thermally decomposing $\mathrm{Mn}\left(\mathrm{NO}_{3}\right)_{2}$ in air for $2 \mathrm{~h}$ at different temperatures $\left(200,300\right.$, and $\left.400^{\circ} \mathrm{C}\right)$.

Electrochemical measurements for the prepared manganese oxide/CNT/Al foil composite electrodes or the prepared manganese oxide/CNT/nanoporous alumina templates composite electrodes were performed using an electrochemical analyzer (CH Instruments CHI 608B, USA). The threeelectrode cell consisted of $\mathrm{Ag} / \mathrm{AgCl}$ as the reference electrode, $\mathrm{Pt}$ as the counter electrode, and the prepared electrode as the working electrode. The electrolytes were degassed with purified nitrogen gas before voltammetric analysis and nitrogen was passed over the solution during all the measurements. The solution temperature was maintained at $25^{\circ} \mathrm{C}$ by means of a circulating water thermostat (HAAKE DC3 and K20, Germany). Cyclic voltammetry (CV) in the range of $0-1 \mathrm{~V}$ was taken with a $0.5 \mathrm{M}$ aqueous electrolyte $\left(\mathrm{Na}_{2} \mathrm{SO}_{4}\right)$ for the prepared electrode. A CV scan rate of $100 \mathrm{mV} \mathrm{s}^{-1}$ was used in all measurements unless otherwise stated. Geometric specific capacitance $\left(\mathrm{mF} \mathrm{cm}^{-2}\right)$ was utilized unless otherwise stated.

Surface morphologies of the manganese oxide (formed by thermally decomposing $\mathrm{Mn}\left(\mathrm{NO}_{3}\right)_{2}$ at $300^{\circ} \mathrm{C}$ )/CNT (treated with acid for $5 \mathrm{~min}$ ) composite electrodes with an $\mathrm{Al}$ foil as a substrate and with nanoporous alumina templates as a substrate before or after potential cycling were conducted by a field emission scanning electron microscope (FE-SEM, JEOL JSM-6700F, Japan). Furthermore, an X-ray diffractometer (XRD, Bruker AXS SMART APEX CCD, Germany) with low angles of incidence was used to characterize the crystalline structure of the CNT (treated with acid for $5 \mathrm{~min}$ )/Al foil electrode and the manganese oxide (formed by thermally decomposing $\mathrm{Mn}\left(\mathrm{NO}_{3}\right)_{2}$ at different temperatures)/CNT (treated with acid for $5 \mathrm{~min}$ )/Al foil composite electrode. Moreover, the intensity ratios of the $\mathrm{C}-\mathrm{C}$ stretching mode to the disorder-induced mode of graphite structure for CNTs treated with acid at different times and CNTs annealed at different temperatures were investigated by a microscope Raman spectrometer (inVia, Renishaw, UK). The chemical environment of the manganese oxide (formed by thermally decomposing $\mathrm{Mn}\left(\mathrm{NO}_{3}\right)_{2}$ at $300^{\circ} \mathrm{C}$ )/CNT (treated with acid for $5 \mathrm{~min}$ )/Al foil composite electrode before and after potential cycling was explored by X-ray photoemission spectroscopy (XPS, Kratos AXIS Ultra DLD, Japan). 


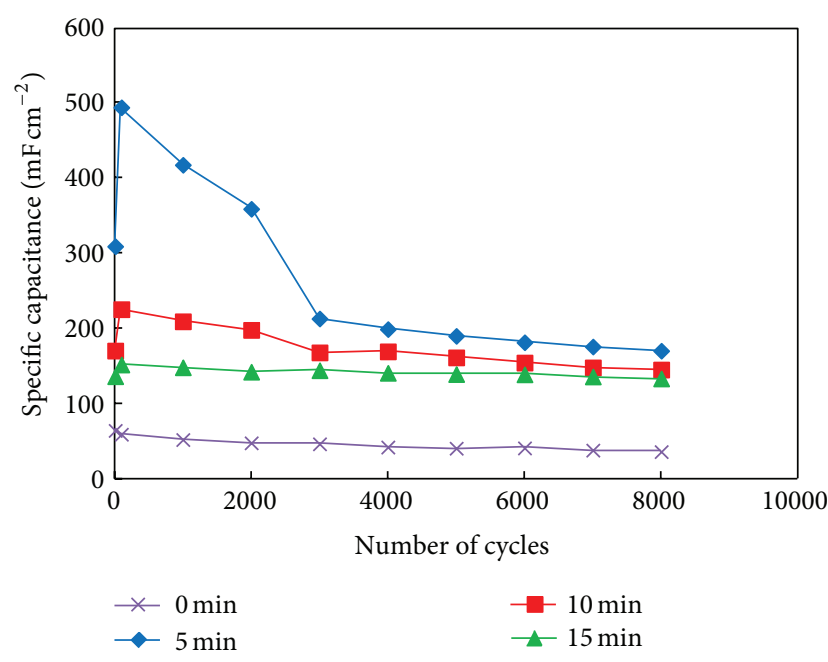

FIGURE 1: The effects of time of acid treatment for the CNTs and different charge-discharge cycles on the specific capacitance of the manganese oxide (formed by thermally decomposing $\mathrm{Mn}\left(\mathrm{NO}_{3}\right)_{2}$ at $\left.300^{\circ} \mathrm{C}\right) / \mathrm{CNT} / \mathrm{Al}$ foil composite electrode.

\section{Results and Discussion}

Figure 1 shows the effects of time of acid treatment for the CNTs and different charge-discharge cycles on the specific capacitance of the manganese oxide (formed by thermally decomposing $\mathrm{Mn}\left(\mathrm{NO}_{3}\right)_{2}$ at $\left.300^{\circ} \mathrm{C}\right) / \mathrm{CNT} / \mathrm{Al}$ foil composite electrode. For no acid treatment for CNTs $(0 \mathrm{~min})$, their performance of the specific capacitance was worse than that of others $(5,10$, and $15 \mathrm{~min})$. The reason behind this behavior may be that after the CNTs being treated with acid, the CNTs were transformed from the hydrophobic nature (contact angle of about $154^{\circ}$ ) to the hydrophilic nature (contact angle of about $3^{\circ}-4^{\circ}$ ) which led to an increase in the amount (from $0.005 \mathrm{mg} \mathrm{cm}^{-2}$ to $1.14-2.52 \mathrm{mg} \mathrm{cm}^{-2}$ ) of manganese oxide (electroactive material) coated on the CNTs, thus leading to an increase in the capacitance. Furthermore, at the 100th cycle of potential cycle, the shorter the acid treatment time, the higher the specific capacitance of the CNTs (see Figure 1) since the shorter the treatment time, the greater the amount of manganese oxide coated on the CNTs (see Table 1), thus leading to an increase in the specific capacitance. Moreover, during the 100-3000 cycles of potential cycling, the longer the time that the CNTs were treated with acid, the slower the decreasing rate of the specific capacitance (see Figure 1) because the longer the time, the higher the intensity ratio of the C-C stretching mode to the disorder-induced mode of graphite structure for carbon products (see Table 1).

Figure 2 shows the effects of annealing temperatures of the CNTs and different charge-discharge cycles on the specific capacitance of the manganese oxide (formed by thermally decomposing $\mathrm{Mn}\left(\mathrm{NO}_{3}\right)_{2}$ at $\left.300^{\circ} \mathrm{C}\right) / \mathrm{CNT} / \mathrm{Al}$ foil composite electrode. At the 100th cycle of potential cycle, the higher the annealing temperature of the CNTs, the higher the specific capacitance (see Figure 2). The reason behind this behavior may be that the higher the annealing temperature of the

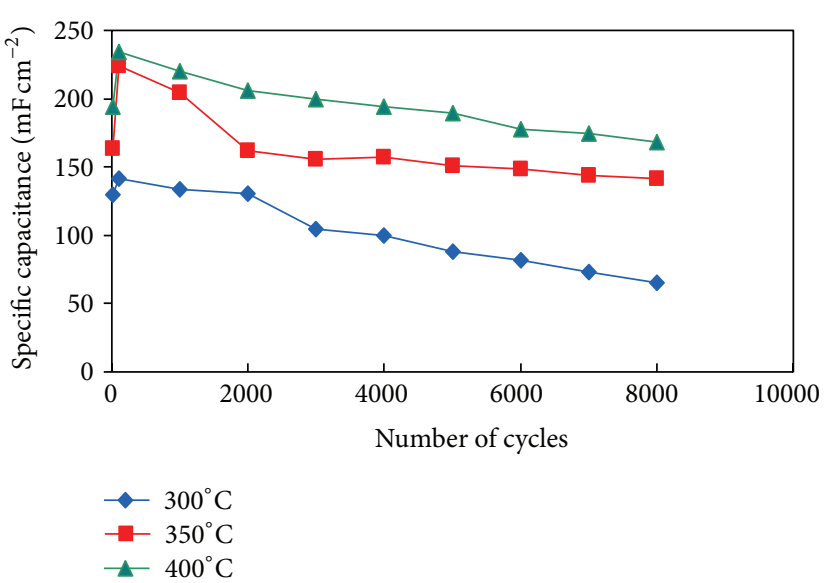

Figure 2: The effects of annealing temperatures of the CNTs and different charge-discharge cycles on the specific capacitance of the manganese oxide (formed by thermally decomposing $\mathrm{Mn}\left(\mathrm{NO}_{3}\right)_{2}$ at $\left.300^{\circ} \mathrm{C}\right) / \mathrm{CNT} / \mathrm{Al}$ foil composite electrode.

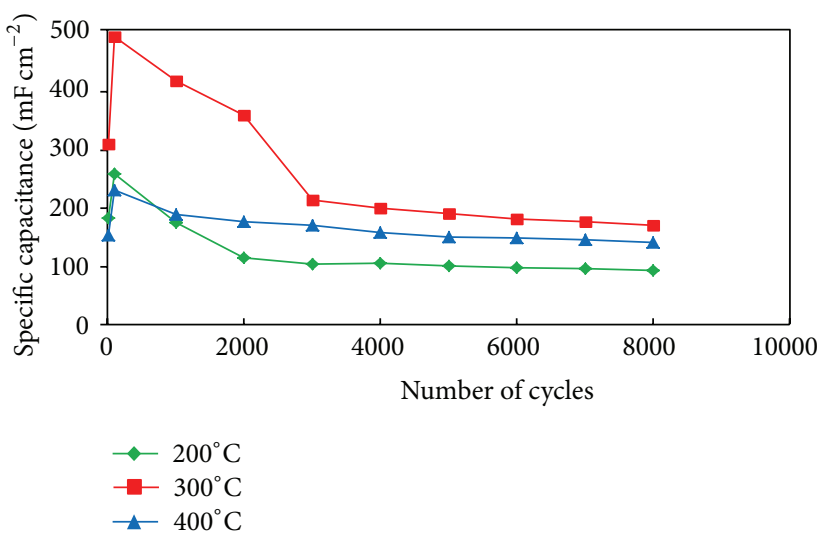

FIGURE 3: The effects of thermal decomposition temperatures of $\mathrm{Mn}\left(\mathrm{NO}_{3}\right)_{2}$ and different charge-discharge cycles on the specific capacitance of the manganese oxide/CNT (treated with acid for $5 \mathrm{~min}) / \mathrm{Al}$ foil composite electrode.

CNTs, the more the electroactive manganese oxide deposited on the CNTs annealed (see Table 1), consequently leading to higher capacitance. Furthermore, during the $100-8000$ cycles of potential cycling, the higher the annealing temperature, the slower the decreasing rate of the specific capacitance (see Figure 2). This picture may be explained because the higher the annealing temperature of the CNTs, the greater the amount of organized carbon material (see Table 1).

Therefore, those CNTs treated with acid for 5 min were chosen as better/superior modification method/condition due to a higher capacitance at the 8000th cycle of potential cycling (see Figures 1 and 2) and the shortest time.

Figure 3 shows the effects of thermal decomposition temperatures of $\mathrm{Mn}\left(\mathrm{NO}_{3}\right)_{2}$ and different charge-discharge cycles on the specific capacitance of the manganese oxide/CNT 
TABLE 1: The amount of immersion/thermal decomposition of manganese oxide and $I_{G} / I_{D}$ of the CNTs modified by different methods and conditions.

\begin{tabular}{lcc}
\hline CNTs modified by different methods and conditions & Amount of immersion/decomposition of manganese oxide, $\mathrm{mg} \mathrm{cm}^{-2}$ & $I_{G} / I_{D}$ \\
\hline CNTs treated with acid for $5 \mathrm{~min}$ & 2.52 & 0.936 \\
CNTs treated with acid for $10 \mathrm{~min}$ & 1.40 & 1.005 \\
$\mathrm{CNTs}$ treated with acid for $15 \mathrm{~min}$ & 1.14 & 1.028 \\
$\mathrm{CNTs}$ annealed at $300^{\circ} \mathrm{C}$ & 0.65 & 0.985 \\
$\mathrm{CNTs}$ annealed at $350^{\circ} \mathrm{C}$ & 1.13 & 0.991 \\
CNTs annealed at $400^{\circ} \mathrm{C}$ & 1.64 & 1.009 \\
\hline
\end{tabular}

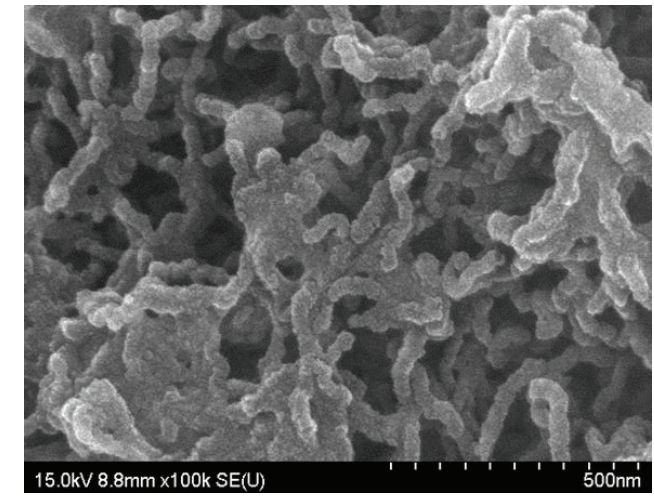

(a)

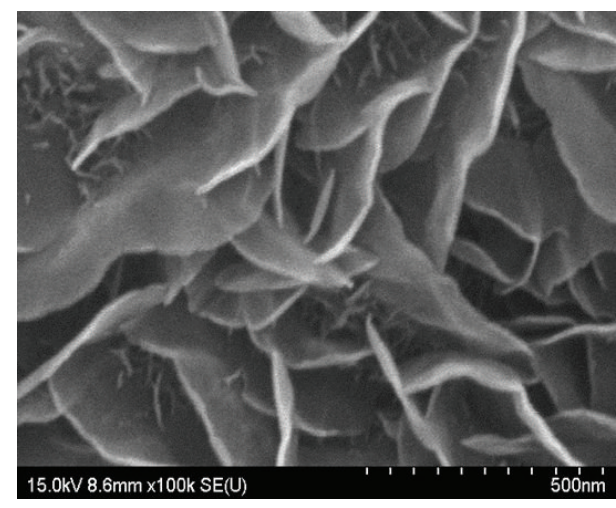

(c)

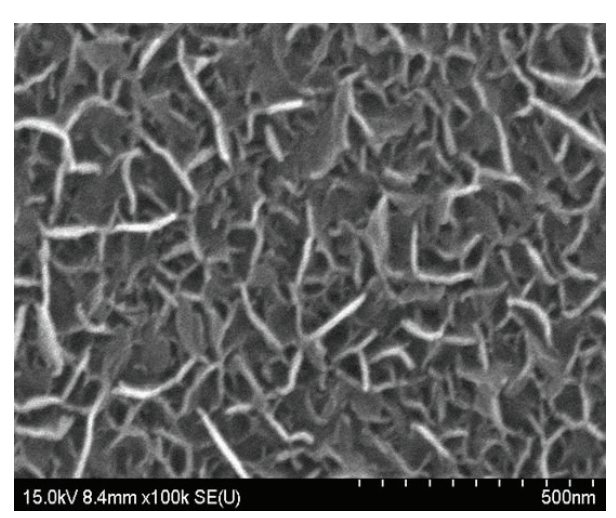

(b)

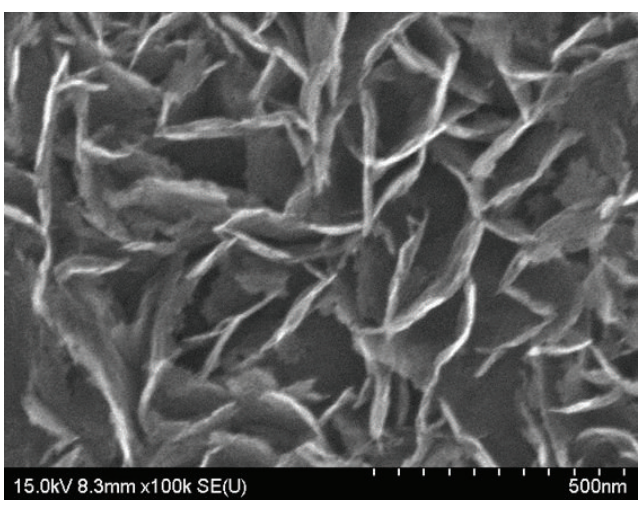

(d)

FIGURE 4: Surface morphologies of the manganese oxide (formed by thermally decomposing $\mathrm{Mn}\left(\mathrm{NO}_{3}\right)_{2}$ at $300^{\circ} \mathrm{C}$ )/CNT (treated with acid for $5 \mathrm{~min}$ )/Al foil composite electrode (a) before potential cycling and after potential cycling, (b) at 10 cycles, (c) at 100 cycles, and (d) at 1000 cycles.

(treated with acid for $5 \mathrm{~min}$ )/ $\mathrm{Al}$ foil composite electrode. The specific capacitance reached a maximum at the 100th cycle of potential cycle. The reason behind this behavior may be explained as follows. Surface morphologies of the manganese oxide (formed by thermally decomposing $\mathrm{Mn}\left(\mathrm{NO}_{3}\right)_{2}$ at $\left.300^{\circ} \mathrm{C}\right) / \mathrm{CNT}$ (treated with acid for $5 \mathrm{~min}$ )/ $\mathrm{Al}$ foil composite electrode before potential cycling and after potential cycling 10, 100, and 1000 cycles are shown in Figures 4(a), 4(b), 4(c), and 4(d), respectively. The surface of the manganese oxide/CNT/Al foil composite electrode (see Figure 4(a)) revealed that manganese oxides were coated on the surface of CNTs and distributed in the CNT entangled matrix; the surface of the manganese oxide/CNT/Al foil composite electrode at 10 cycles of potential cycling (see Figure 4(b)) revealed a small three-dimensional network of flakes; the surface of the manganese oxide/CNT/Al foil composite electrode at 100 cycles of potential cycling (see Figure 4(c)) revealed a large three-dimensional network of flakes which led to increasing surface area as well as then increasing specific capacitance; and the surface of the manganese oxide/CNT/Al foil composite electrode at 1000 cycles of potential cycling (see Figure $4(\mathrm{~d})$ ) revealed that parts of three-dimensional network of flakes were dissolved which led to decreasing surface area as well as finally decreasing specific capacitance. XPS spectral data of Mn 2 $\mathrm{p}_{3 / 2}, \mathrm{Mn} 3 \mathrm{~s}$, and $\mathrm{O} 1 \mathrm{~s}$ for the manganese oxide (formed by thermally decomposing $\mathrm{Mn}\left(\mathrm{NO}_{3}\right)_{2}$ at $300^{\circ} \mathrm{C}$ )/CNT (treated with acid for $5 \mathrm{~min}$ )/Al foil composite electrode before and after potential cycling $(10,100$, and 1000 cycles) are also listed in Table 2 . The differences of binding energy between the splitting peaks of 


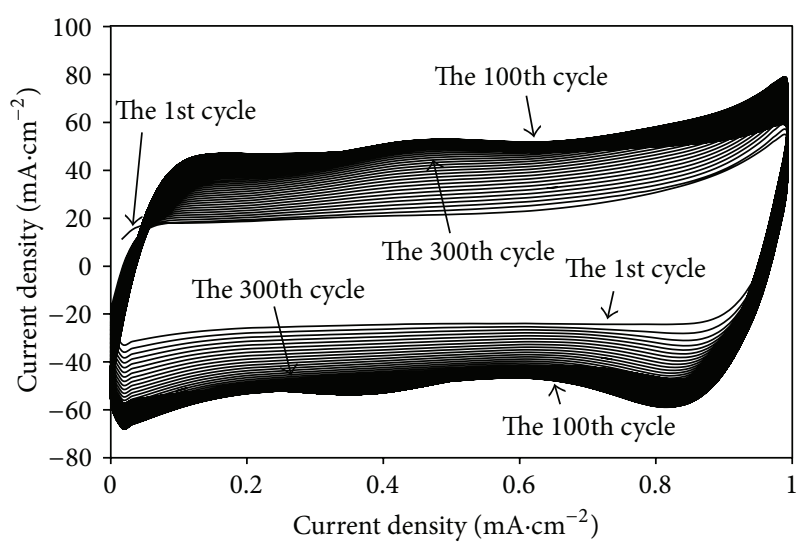

FIGURE 5: The charge-discharge cycles of the manganese oxide (formed by thermally decomposing $\mathrm{Mn}\left(\mathrm{NO}_{3}\right)_{2}$ at $300^{\circ} \mathrm{C}$ )/CNT (treated with acid for $5 \mathrm{~min}$ )/Al foil composite electrode.

Mn $3 \mathrm{~s}$ in Table 2 changed from $5.2 \mathrm{eV}$ to $4.8 \mathrm{eV}$ and $4.9 \mathrm{eV}$ for manganese oxide following the 100 and 1000 cycles of potential cycling. The difference of binding energy between the splitting peaks of $\mathrm{Mn} 3 \mathrm{~s}$ decreases with increasing valence of manganese oxide [25-27], so manganese oxide before CV as well as after 10 cycles of potential cycling mainly consists of $\mathrm{Mn}^{3+}$ species; manganese oxide after 100 cycles of potential cycling consists of $\mathrm{Mn}^{4+}$ species; and manganese oxide after 1000 cycles of potential cycling almost consists of $\mathrm{Mn}^{4+}$ species. Therefore, the specific capacitance reached a maximum at the 100th cycle of potential cycle since the larger the amount of trivalent manganese oxide, the higher the specific capacitance [28]. From the Mn 3s and O 1s data in Table 2, the difference of binding energy between the splitting peaks of Mn 3s decreased with decreasing the amount of $\mathrm{Mn}-\mathrm{OH}$ (hydroxide). Similar results have been published in previous reports in the literature $[25,26]$. From the $\mathrm{O} 1 \mathrm{~s}$ data in Table 2, the greater the number of cycles, the greater the amount of $\mathrm{H}-\mathrm{O}-\mathrm{H}$ (water). The charge-discharge cycles of the manganese oxide (formed by thermally decomposing $\mathrm{Mn}\left(\mathrm{NO}_{3}\right)_{2}$ at $\left.300^{\circ} \mathrm{C}\right) / \mathrm{CNT}$ (treated with acid for $5 \mathrm{~min}$ )/ $\mathrm{Al}$ foil composite electrode were investigated in Figure 5, which shows from the 1st to 300th charge-discharge cycle, the area enclosed by 100th charge-discharge cycle is the largest and then the specific capacitance reached a maximum at the 100th cycle of potential cycle. Furthermore, X-ray diffraction patterns of the CNT (treated with acid for $5 \mathrm{~min}$ )/ $\mathrm{Al}$ foil electrode and the manganese oxide (formed by thermally decomposing $\mathrm{Mn}\left(\mathrm{NO}_{3}\right)_{2}$ at 200,300 , and $\left.400^{\circ} \mathrm{C}\right) / \mathrm{CNT}$ (treated with acid for $5 \mathrm{~min}$ )/ $\mathrm{Al}$ foil composite electrode are shown in Figures 6(a), 6(b), 6(c), and 6(d), respectively. The operational stability for thermal decomposition of $\mathrm{Mn}\left(\mathrm{NO}_{3}\right)_{2}$ at $400^{\circ} \mathrm{C}$ is better than that for thermal decomposition of $\mathrm{Mn}\left(\mathrm{NO}_{3}\right)_{2}$ at $200^{\circ} \mathrm{C}$ or $300^{\circ} \mathrm{C}$ since more crystal peaks appeared for thermal decomposition of $\mathrm{Mn}\left(\mathrm{NO}_{3}\right)_{2}$ at $400^{\circ} \mathrm{C}$ by comparing Figures $6(\mathrm{~b}), 6(\mathrm{c})$, and $6(\mathrm{~d})$. However, the thermal decomposition temperature of $\mathrm{Mn}\left(\mathrm{NO}_{3}\right)_{2}$ at $300^{\circ} \mathrm{C}$ was chosen as the best condition due to a higher capacitance

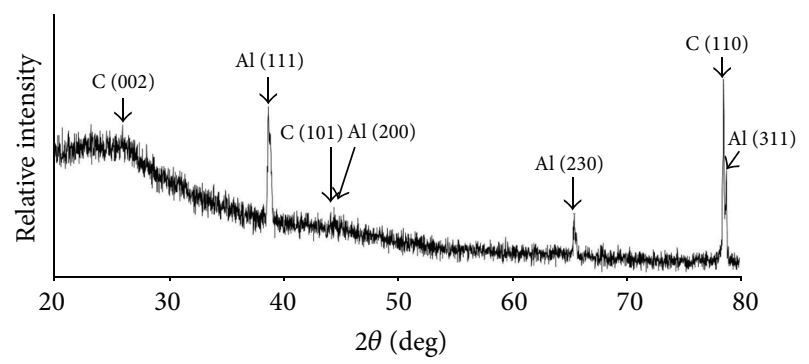

(a)

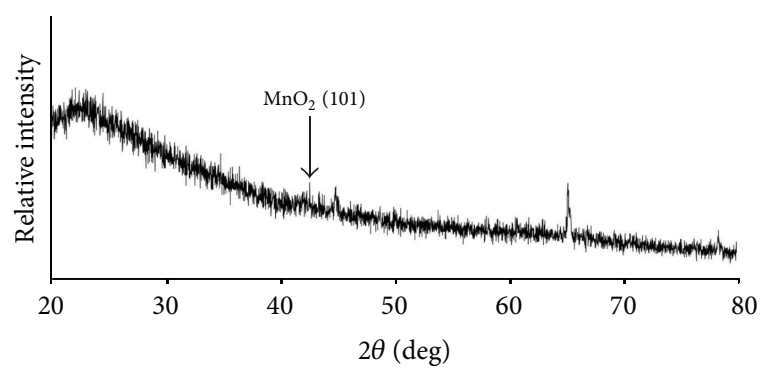

(b)

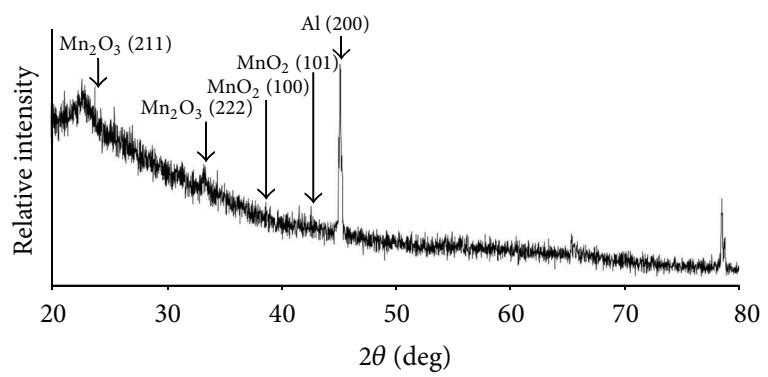

(c)

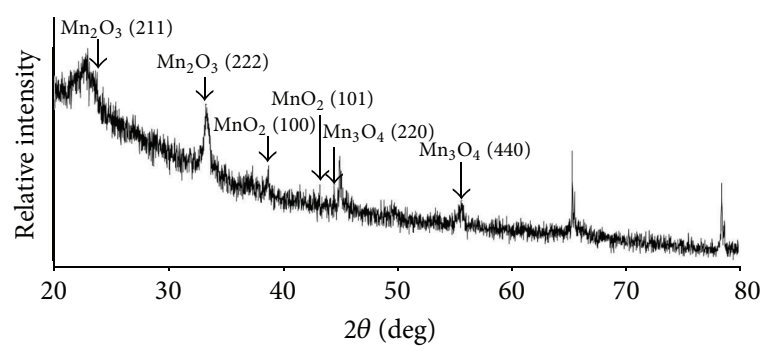

(d)

FIGURE 6: X-ray diffraction patterns of (a) the CNT (treated with acid for $5 \mathrm{~min}$ )/Al foil electrode and the manganese oxide (formed by thermally decomposing $\mathrm{Mn}\left(\mathrm{NO}_{3}\right)_{2}$ at (b) $200^{\circ} \mathrm{C}$, (c) $300^{\circ} \mathrm{C}$, and (d) $400^{\circ} \mathrm{C}$ )/CNT (treated with acid for $5 \mathrm{~min}$ )/Al foil composite electrode.

at the 8000th cycle of potential cycling (see Figure 3) and a lower temperature. Moreover, the main chemical reaction for thermal decomposition of manganese nitrate solution is $\mathrm{Mn}\left(\mathrm{NO}_{3}\right)_{2} \rightarrow \mathrm{MnO}_{2}+2 \mathrm{NO}_{2}$; but manganese in manganese nitrate is not being completely oxidized to $\mathrm{Mn}(\mathrm{IV})$ during thermal decomposition; instead, $\mathrm{Mn}(\mathrm{II})$ and $\mathrm{Mn}(\mathrm{III})$ are byproducts of the above reaction [29]. 
TABLE 2: Mn 2 $\mathrm{p}_{3 / 2}$, Mn 3s, and O 1s of XPS for manganese oxide before and after potential cycling.

\begin{tabular}{|c|c|c|c|c|c|c|c|}
\hline & & & & Sample & & & \\
\hline & $\operatorname{Mn} 2 p_{3 / 2}$ & & $\mathrm{Mn} 3 \mathrm{~s}$ & & Band & & \\
\hline & $\mathrm{Eb}, \mathrm{eV}$ & $\mathrm{Eb}(1), \mathrm{eV}$ & $\mathrm{Eb}(2), \mathrm{eV}$ & $\Delta E, \mathrm{eV}$ & band & $\mathrm{Eb}, \mathrm{eV}$ & Area, \% \\
\hline & & & & & $\mathrm{Mn}-\mathrm{O}-\mathrm{Mn}$ & 529.13 & 67.58 \\
\hline Before CV & 641.4 & 83.1 & 88.3 & 5.2 & $\mathrm{Mn}-\mathrm{OH}$ & 530.49 & 24.86 \\
\hline & & & & & $\mathrm{H}-\mathrm{O}-\mathrm{H}$ & 531.85 & 7.29 \\
\hline & & & & & $\mathrm{Mn}-\mathrm{O}-\mathrm{Mn}$ & 529.14 & 47.14 \\
\hline 10 cycles & 641.7 & 83.4 & 88.6 & 5.2 & $\mathrm{Mn}-\mathrm{OH}$ & 530.44 & 24.19 \\
\hline & & & & & $\mathrm{H}-\mathrm{O}-\mathrm{H}$ & 531.43 & 28.67 \\
\hline & & & & & $\mathrm{Mn}-\mathrm{O}-\mathrm{Mn}$ & 529.13 & 47.62 \\
\hline 100 cycles & 641.7 & 83.6 & 88.4 & 4.8 & $\mathrm{Mn}-\mathrm{OH}$ & 530.18 & 16.69 \\
\hline & & & & & $\mathrm{H}-\mathrm{O}-\mathrm{H}$ & 531.32 & 30.31 \\
\hline & & & & & $\mathrm{Mn}-\mathrm{O}-\mathrm{Mn}$ & 529.42 & 29.99 \\
\hline 1000 cycles & 641.8 & 83.9 & 88.8 & 4.9 & $\mathrm{Mn}-\mathrm{OH}$ & 530.65 & 20.52 \\
\hline & & & & & $\mathrm{H}-\mathrm{O}-\mathrm{H}$ & 531.6 & 49.49 \\
\hline
\end{tabular}

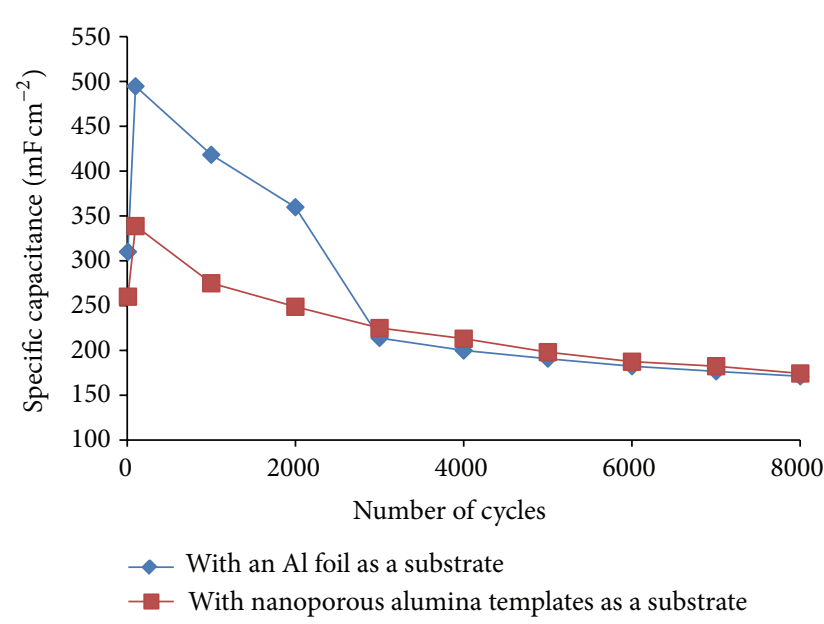

FIgURE 7: The effects of different charge-discharge cycles on the specific capacitance of the manganese oxide (formed by thermally decomposing $\mathrm{Mn}\left(\mathrm{NO}_{3}\right)_{2}$ at $300^{\circ} \mathrm{C}$ )/CNT (treated with acid for $5 \mathrm{~min}$ ) composite electrodes with an $\mathrm{Al}$ foil as a substrate and with nanoporous alumina templates as a substrate.

Figure 7 shows the effects of different charge-discharge cycles on the specific capacitance of the manganese oxide (formed by thermally decomposing $\mathrm{Mn}\left(\mathrm{NO}_{3}\right)_{2}$ at $300^{\circ} \mathrm{C}$ )/ CNT (treated with acid for $5 \mathrm{~min}$ ) composite electrodes with an $\mathrm{Al}$ foil as a substrate and with nanoporous alumina templates as a substrate. At the 100th cycle of potential cycle, the capacitance with an $\mathrm{Al}$ foil as a substrate was higher than that with nanoporous alumina templates as a substrate because of the rigid structure of the CNTs grown on nanoporous alumina templates. However, the operational stability with nanoporous alumina templates as a substrate was better than that with an Al foil as a substrate since the surface of the manganese oxide/CNT composite electrode with nanoporous alumina templates as a substrate maintained more threedimensional network of flakes compared with the surface

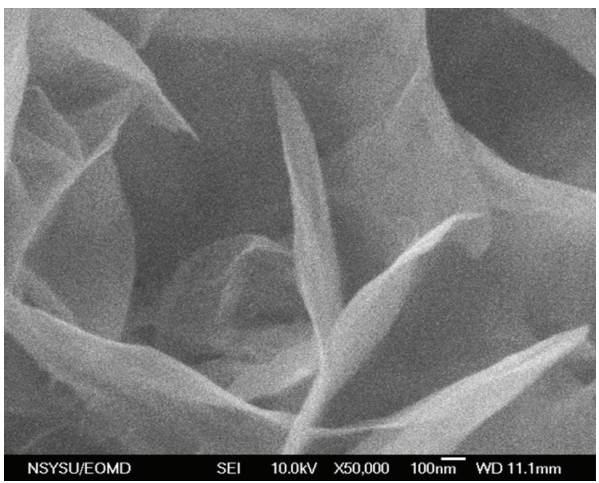

(a)

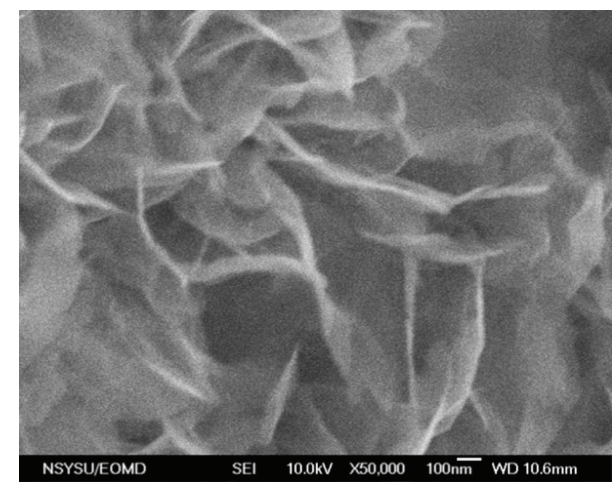

(b)

FIGURE 8: Surface morphologies of the manganese oxide (formed by thermally decomposing $\mathrm{Mn}\left(\mathrm{NO}_{3}\right)_{2}$ at $300^{\circ} \mathrm{C}$ )/CNT (treated with acid for $5 \mathrm{~min}$ ) composite electrodes (a) with an $\mathrm{Al}$ foil as a substrate and (b) with nanoporous alumina templates as a substrate at 8000 cycles of potential cycling.

of the manganese oxide/CNT composite electrode with an $\mathrm{Al}$ foil as a substrate at 8000 cycles of potential cycling (see Figure 8). 


\section{Conclusions}

The specific capacitance reached a maximum at the 100th cycle of potential cycle. At the 100th cycle of potential cycling, the shorter the duration that the CNTs were treated with acid, the higher the specific capacitance and the higher the annealing temperature of the CNTs, the higher the specific capacitance. Furthermore, the CNTs treated with acid for 5 min were adopted as a better modification method as well as providing a superior condition and a thermal decomposition temperature of $\mathrm{Mn}\left(\mathrm{NO}_{3}\right)_{2}$ at $300^{\circ} \mathrm{C}$ was chosen as the best.

\section{Acknowledgment}

Financial support by the National Science Council China (under Grant no. NSC 100-2221-E-224-036) is gratefully acknowledged.

\section{References}

[1] B. E. Conway, Electrochemical Supercapacitors-Scientific Fundamentals and Technological Applications, Kluwer Academic/ Plenum Publishers, New York, NY, USA, 1999.

[2] R. Kötz and M. Carlen, "Principles and applications of electrochemical capacitors," Electrochimica Acta, vol. 45, no. 15-16, pp. 2483-2498, 2000.

[3] J. H. Chen, W. Z. Li, D. Z. Wang, S. X. Yang, J. G. Wen, and Z. F. Ren, "Electrochemical characterization of carbon nanotubes as electrode in electrochemical double-layer capacitors," Carbon, vol. 40, no. 8, pp. 1193-1197, 2002.

[4] Y.-S. Chen and C.-C. Hu, "Capacitive characteristics of binary manganese-nickel oxides prepared by anodic deposition," Electrochemical and Solid-State Letters, vol. 6, no. 10, pp. A210-A213, 2003.

[5] Y. U. Jeong and A. Manthiram, "Nanocrystalline manganese oxides for electrochemical capacitors with neutral electrolytes," Journal of the Electrochemical Society, vol. 149, no. 11, pp. A1419A1422, 2002.

[6] C.-C. Hu and C.-C. Wang, "Nanostructures and capacitive characteristics of hydrous manganese oxide prepared by electrochemical deposition," Journal of the Electrochemical Society, vol. 150, no. 8, pp. A1079-A1084, 2003.

[7] J. H. Park, O. O. Park, K. H. Shin, C. S. Jin, and J. H. Kim, "An electrochemical capacitor based on a $\mathrm{Ni}(\mathrm{OH})_{2}$ /activated carbon composite electrode," Electrochemical and Solid-State Letters, vol. 5, no. 2, pp. H7-H10, 2002.

[8] R. N. Reddy and R. G. Reddy, "Sol-gel $\mathrm{MnO}_{2}$ as an electrode material for electrochemical capacitors," Journal of Power Sources, vol. 124, no. 1, pp. 330-337, 2003.

[9] A. Burke, "Ultracapacitors: why, how, and where is the technology," Journal of Power Sources, vol. 91, no. 1, pp. 37-50, 2000.

[10] J.-K. Chang, C.-T. Lin, and W.-T. Tsai, "Manganese oxide/carbon composite electrodes for electrochemical capacitors," Electrochemistry Communications, vol. 6, no. 7, pp. 666-671, 2004.

[11] M. S. Hong, S. H. Lee, and S. W. Kim, "Use of KCl aqueous electrolyte for $2 \mathrm{~V}$ manganese oxide/activated carbon hybrid capacitor," Electrochemical and Solid-State Letters, vol. 5, no. 10, pp. A227-A230, 2002.

[12] J. H. Park, J. M. Ko, and O. O. Park, "Carbon nanotube $/ \mathrm{RuO}_{2}$ nanocomposite electrodes for supercapacitors," Journal of the Electrochemical Society, vol. 150, no. 7, pp. A864-A867, 2003.
[13] J.-R. Zhang, B. Chen, W.-K. Li, J.-J. Zhu, and L.-P. Jiang, "Electrochemical behavior of amorphous hydrous ruthenium oxide/active carbon composite electrodes for super-capacitor," International Journal of Modern Physics B, vol. 16, no. 28-29, pp. 4479-4483, 2002.

[14] C.-C. Lin and R.-C. Wei, "Nitrogen-plasma treatment of carbon nanotubes and chemical liquid phase deposition of alumina for electrodes of aluminum electrolytic capacitors," Journal of the Electrochemical Society, vol. 159, no. 5, pp. A664-A668, 2012.

[15] J. H. Chen, W. Z. Li, D. Z. Wang, S. X. Yang, J. G. Wen, and Z. F. Ren, "Electrochemical characterization of carbon nanotubes as electrode in electrochemical double-layer capacitors," Carbon, vol. 40, no. 8, pp. 1193-1197, 2002.

[16] R. Z. Ma, J. Liang, B. Q. Wei, B. Zhang, C. L. Xu, and D. H. Wu, "Study of electrochemical capacitors utilizing carbon nanotube electrodes," Journal of Power Sources, vol. 84, no. 1, pp. 126-129, 1999.

[17] F. Picó, J. M. Rojo, and M. L. Sanjuán, "Single-walled carbon nanotubes as electrodes in supercapacitors," Journal of The Electrochemical Society, vol. 151, pp. A831-A837, 2004.

[18] S. Delpeux, K. Szostak, E. Frackowiak, and F. Béguin, "An efficient two-step process for producing opened multi-walled carbon nanotubes of high purity," Chemical Physics Letters, vol. 404, no. 4-6, pp. 374-378, 2005.

[19] Z.-Q. Liu, J. Ma, Y.-H. Cui, L. Zhao, and B.-P. Zhang, "Influence of different heat treatments on the surface properties and catalytic performance of carbon nanotube in ozonation," Applied Catalysis B, vol. 101, no. 1-2, pp. 74-80, 2010.

[20] R. Marega, G. Accorsi, M. Meneghetti, A. Parisini, M. Prato, and D. Bonifazi, "Cap removal and shortening of double-walled and very-thin multi-walled carbon nanotubes under mild oxidative conditions," Carbon, vol. 47, no. 3, pp. 675-682, 2009.

[21] C.-C. Lin and J.-H. Jhan, "Influence of substrate treatment temperatures and bias potential on capacitive manganese-cobaltzinc oxide thin films deposited by radio frequency sputtering," Electrochimica Acta, vol. 56, no. 19, pp. 6757-6763, 2011.

[22] C.-C. Lin and H.-W. Chen, "Coating manganese oxide onto graphite electrodes by immersion for electrochemical capacitors," Electrochimica Acta, vol. 54, no. 11, pp. 3073-3077, 2009.

[23] Z. Fan, J. Chen, M. Wang, K. Cui, H. Zhou, and Y. Kuang, "Preparation and characterization of manganese oxide/CNT composites as supercapacitive materials," Diamond and Related Materials, vol. 15, no. 9, pp. 1478-1483, 2006.

[24] Z. Fan, J. Chen, K. Cui, F. Sun, Y. Xu, and Y. Kuang, "Preparation and capacitive properties of cobalt-nickel oxides/carbon nanotube composites," Electrochimica Acta, vol. 52, no. 9, pp. 29592965, 2007.

[25] M. Chigane and M. Ishikawa, "Manganese oxide thin film preparation by potentiostatic electrolyses and electrochromism," Journal of the Electrochemical Society, vol. 147, no. 6, pp. 2246-2251, 2000.

[26] M. Chigane, M. Ishikawa, and M. Izaki, "Preparation of manganese oxide thin films by electrolysis/chemical deposition and electrochromism," Journal of the Electrochemical Society, vol. 148, no. 7, pp. D96-D101, 2001.

[27] M. Toupin, T. Brousse, and D. Bélanger, "Charge storage mechanism of $\mathrm{MnO}_{2}$ electrode used in aqueous electrochemical capacitor," Chemistry of Materials, vol. 16, pp. 3184-3190, 2004.

[28] J.-K. Chang and W.-T. Tsai, "Material characterization and electrochemical performance of hydrous manganese oxide electrodes for use in electrochemical pseudocapacitors," Journal of 
the Electrochemical Society, vol. 150, no. 10, pp. A1333-A1338, 2003.

[29] C.-H. Huang, W.-Y. Shu, H.-M. Wu, H.-J. Shy, and S. C. Wei, "Effect of ammonium nitrate on the conductivity of pyrolytic manganese dioxide," Tamkang Journal of Science and Engineering, vol. 11, no. 4, pp. 325-330, 2008. 

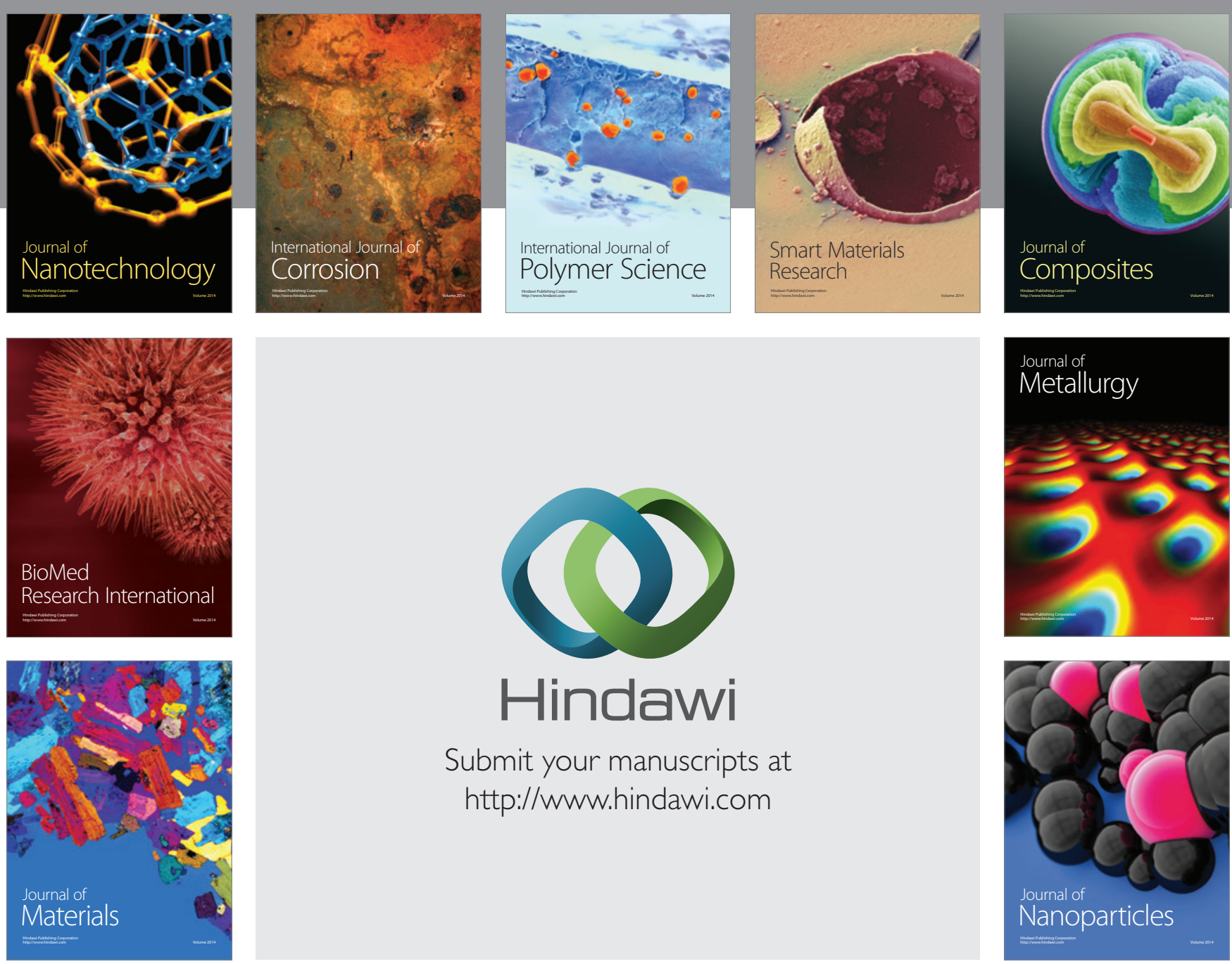

Submit your manuscripts at http://www.hindawi.com
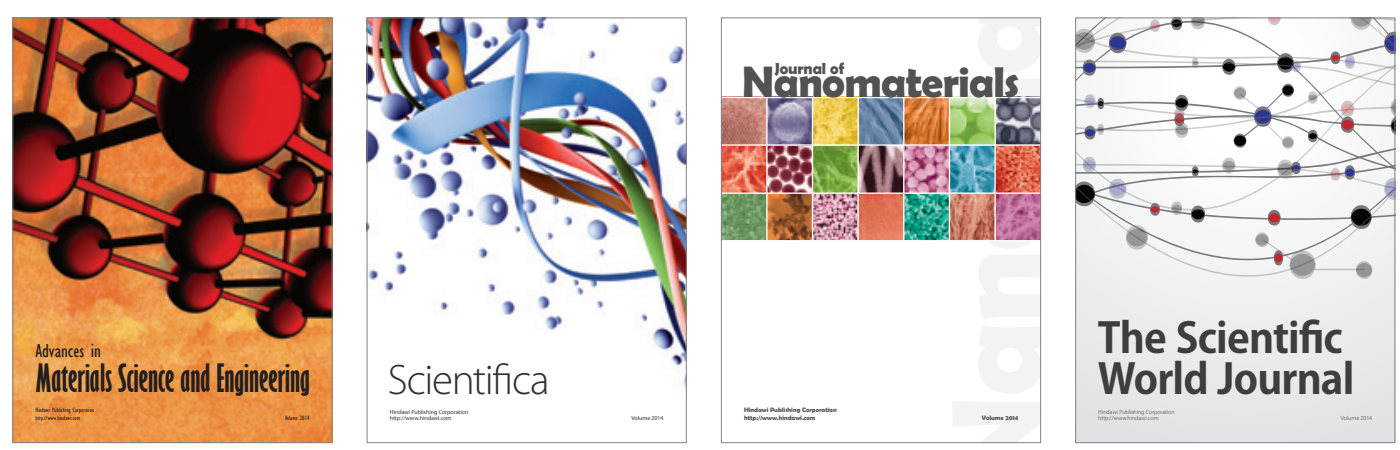

\section{The Scientific World Journal}
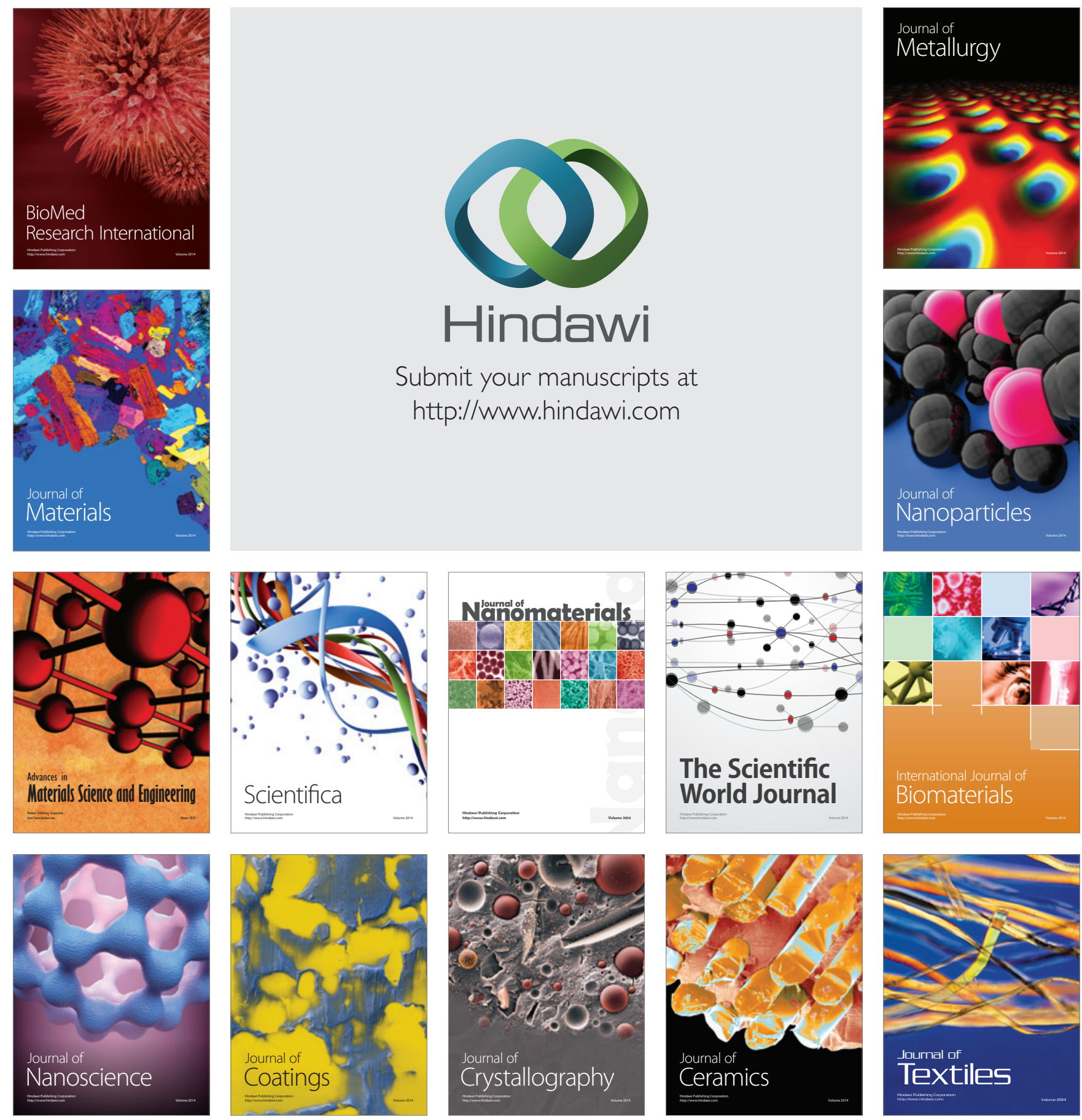